\title{
AICDA Gene
}

National Cancer Institute

\section{Source}

National Cancer Institute. AICDA Gene. NCI Thesaurus. Code C101413.

This gene plays a role in both class-switch recombination in B-lymphocytes and cytidine deamination. 